KULTURA I WARTOŚCI

ISSN 2299-7806

NR 14/ 2015

ARTYKULY, s. 97-109

\title{
THE INDIVIDUAL AND THE COMMUNITY - A STUDY OF TWO CASES
}

\begin{abstract}
Andrzej Ostrowski
The aim of the article is to discuss the problem of relationship between the individual and the community. The context of the analysis is provided by two models of the organization of social life, which were proposed by Vladimir S. Solovyov and Lev I. Shestov. The first of these models is typified by the escape from the community to the self. The second model is characterised by the escape from the self to the community. In the interpretive approach the two models are understood as a consequence of finding the truth. The discussion is based on the interpretive assumption that while gaining knowledge, both Shestov and Solovyov discovered the same truth - "the essence of the particular and the individual".
\end{abstract}

Keywords: Ethics, individual, community, duty, lies

The starting point for discussion is L. Shestov's words on Dostoevsky and V. Solovyov, "Dostoevsky's philosophy was an escape from the community [omnitude] to the self (ot vsemstva $k$ sebe). In contrast, Solovyov did the opposite: he escaped from the self to the community. For him, the living man or what the school called an empirical individual seemed the main obstacle on the road to truth [...]. A Dostoevsky knew that Truth is revealed in an empirical individual and only in an empirical individual" . Shestov did not hide the fact that Dostoevsky's literary out-

ANDRZEJ OSTROWSKI, dr hab., Uniwersytet Marii Curie-Skłodowskiej w Lublinie, Polska; adres do korespondencji:, Pl. M. Curie-Skłodowskiej 4, 20-031 Lublin, Polska; e-mail: aostrowski@bacon.umcs.lublin.pl

${ }^{1}$ L Shestov, Afiny i Ierusalim, [in:] id., Sochineniya v 2-kh tomakh, Nauka, Moscow, 1993, Vol. I, pp. 653-654. The term 'vsemstvo' (всемство) causes many problems with translation and interpretation. This word does not appear in Russian dictionaries although Shestov, referring to Dostoevsky, frequently uses it in his works. In the context of this discussion, I translate всемство as opposed to the individual as the 'community' [omnitude] in the sense of the universal, the common, the total, the general and necessary. When explaining the meaning of всемство Shestov writes "...this is what is always and everywhere recognized as the truth by all [...]" (L. Shestov, Kierkegard 
put was his source of inspiration. He wrote about it many times; one should also bear in mind that he also drew inspiration from other sources. I will not seek to confirm whether Dostoevsky's philosophy was an escape from the community to the self. I regard this thesis, however, as the way Shestov perceived Dostoevsky's position. Since Shestov regards Solovyov's philosophy as extremely contradictory to his own and because Solovyov's philosophy was often criticized by Shestov, I adopt the assumption that the thesis about the escape from the community to the self also expresses Shestov's position. This means that I interpret Shestov's reference to Dostoevsky as Shestov's attempt to affirm his own views.

Solovyov, escaping from the self to the community, is therefore an example of the position which Shestov criticizes and, consequently, rejects. What is important for further discussion is that one of the sources of Solovyov's philosophy - like Shestov's - was also the literary works of Dostoevsky. To understand the manner in which Solovyov interprets Dostoevsky's view, it is not without significance that they personally knew each other. Because Dostoevsky highly regarded Solovyov's philosophy, some of his (Dostoevsky's) views being similar to what Solovyov advocated, we can speak of their mutual inspiration. The "last word" on the subject belongs to Solovyov, who, in his funeral speech after Dostoevsky's death, presents the latter's views in such a way that as a result he attributes his own philosophical position to him $^{2}$.

These conclusions show that both Solovyov and Shestov try to win Dostoevsky to their side, assuming that the two philosophers take opposite positions as Shestov would have it. Since the common source of inspiration for both philosophers is Dostoevsky's works, some questions may be asked that suggest the need for separate discussions. Is therefore the difference between Solovyov's stand and Shestov's position only apparent or, as Shestov demonstrates, essential enough to make their positions really opposing? If they are, what does the difference consist in? Why is Dostoevsky so important to the two philosophers that they try to win him over to their sides? On whose side should Dostoevsky be listed?.

\footnotetext{
i ekzistentsial'naya filosofiya. Glas vopiyushchego v pustyne, Progress - Gnozis, Moscow 1992, p. 21). It should be added that truth thus understood is deception - обман (ibid.), which should be rejected. In the context of the problem of lying, which I discuss later in the text, the "universal truth" understood as deception has a special significance.

${ }^{2}$ Cf. W. Sołowjow, Trzy mowy ku pamięci Dostojewskiego 1881-1883, [in:] id., Wybór pism, transl. by J. Zychowicz, W Drodze, Poznań 1988, Vol. III, pp. 127-158.
} 


\section{Relationship between the individual and the community}

In Shestov's foregoing statement "the community" was opposed to the "living man" identified with "an empirical individual" or "individual man". Consequently, we can assume that the "community" is equivalent to society and the binding rules and norms in it. The comparison of the individual (individual man) with the community (society) makes it possible to ask about the relationship between these elements.

Assuming the actual existence of a single person known by his/her forename and surname, and of a society characterized by some features, it is possible to try to typologize relationships between the individual and the community. The extreme models of this relationship are characterized by A) the individual's total independence from the community (this model makes sense assuming that the consequence of the individual's normal development consisting in the acquisition of knowledge and attainment of the highest degree of consciousness is the leaving of society); by B) the total dependence of the individual on the community (consequently, the individual cannot exist outside of the community).

With reference to Shestov's cited remark, an example of the A type relationship is Dostoevsky's attitude, which, according to the adopted interpretive assumption, is also represented by Shestov. It consists in the escape from the community to the self. An example of the B type relationship is Solovyov's attitude, which consists in the escape from the self to the community. In the latter case, Dostoevsky should however be mentioned with Solovyov because of the remark on the similarity between the views of Dostoevsky and Solovyov.

\section{Activities of the yurodivy as an example of the relationship between the individual and the community}

An auxiliary premise for further discussion is the statement by C. Wodziński, which shows the example of the contemporary yurodivy [holy fool]: "Some $20^{\text {th }}$-century students of the problem of yurodstvo [insanity, holy foolishness] defend the proposition that the yurodivy's mission was taken over in a (limited) sense by the Russian intelligentsia, especially at the end of the $19^{\text {th }}$ century and at the turn of the $19^{\text {th }}$ century. Indeed, when reading some works (including biographies) of Solovyov, Fyodorov, Rozanov or Shestov, it is sometimes hard to resist the impression that the yurodivy suddenly decided to take cover in the form 
of weird... "philosophical treaties and manifestos «"3. The subject of further discussion is neither the problem of yurodstvo nor yurodivy ${ }^{4}$, but the problem which manifests fully in the example of the yurodivy's way of life when this way is examined in the context of the relationship between the individual and the community.

I also refer to Wodziński's remark because both Solovyov and Shestov are among the philosophers that he mentions. In research terms, the comparison of the two philosophers is interesting since, as has already been emphasized, Shestov treats Solovyov's philosophy as opposed to his own position. On account of the "weirdness of treaties" and their biographies, both Solovyov and Shestov are, however, a good example of the contemporary yurodivy.

A preliminary analysis of the example of the yurodivy gives grounds to assert that the right type of the individual-community relationship, based on which it is possible to explain the specific way of the yurodivy's life, is type A, or the individual's total independence from the community. However, the problem arises when we take into account the fact that the essence of the yurodivy's activities (or even the mission that s/he has to accomplish) manifests only as part of social life. It is revealed only when the yurodivy enters in a negative relationship with others, the context of the relationship being social life in a broad sense.

Both the yurodivy's wisdom manifested through his/her foolishness (holy idiot) and foolishness itself as a means of expressing wisdom can be observed by others only in the context of social life. The community is therefore necessary not only for the yurodivy to be able to act but also for one to understand the essence of his/her activities.

The yurodivy needs society so that, by criticizing it, s/he could accomplish his/her mission. The sense of the yurodivy's adopted lifestyle consists in challenging the model of social life in which s/he had originally come to live, with the reservation that by challenging this model the yurodivy leaves society without, however, going outside of society. The yurodivy leaves society because his/her activity is not meant either to improve a given model of social life or to abolish it and offer an alternative. In most general terms, the goal of the yurodivy's activities is to draw attention to the ultimate matters analyzed in the religious context by challenging the existing order of social life. In view of the indicated problem there are no grounds to continue arguing that the type A of the

\footnotetext{
${ }^{3}$ C. Wodziński, Pan Sokrates. Eseje trzecie, WIFiS PAN, Warszawa 2000, p. 231.

${ }^{4}$ On this subject cf. idem, $S$ w. Idiota. Projekt antropologii apofatycznej, słowo/obraz terytoria, Gdańsk 2009.
} 
individual-community relationship applies to the yurodivy. Nevertheless, the same should be said about type B because the yurodivy clearly leaves society. It can be therefore assumed that one of the essential features of yurodstvo regarding the individual - community relationship is expressed in the thesis: the individual leaves society without going outside of it. In formal terms this proposition can be regarded as type $C$ of the individual - community relationship.

\section{Giving up the general - the case of Shestov}

The problem of the individual giving up the general (e.g. mathematics, ethics, law, norms, and society) was repeatedly discussed by Shestov in many of his works. Therefore, the research material is very rich. I would like to draw attention to two aspects of the problem, and because of the scope of discussion on the individual-community relationship I will identify the term 'the general' only with society.

The first aspect comes down to the condition that has to be met so that we could speak of the individual leaving the community. The realization of the stage of the individual's leaving the community is not easy because the necessary condition to be satisfied, which is pointed out by Shestov, is a highly complex process. "Afterwards, when food in general and everything "in general« that seems to be the necessary condition for living organisms to exist was found and, in particular, when the cultural man [man of culture as its product, A. O.] appeared with large stores of the »in general« so that it became possible once and for all not to worry about them anymore, and so when free time appeared and with it the possibility of being interested not only in necessities but also in anything, then it was only for the first time that the essence of the particular and the individual became fully apparent"5.

The provision of everything "in general" is a social process, consequently, if it is a necessary condition for "the essence of the particular and the individual to come to the fore", it should be first of all emphasized that this essence is revealed through social development in a broad sense. In the context of the present discussion I assume that "the essence of the particular and the individual" will manifest in full only after the individual leaves the community. In this sense, leaving the community is also the aim of the self-realizing individual. The abandonment of the

${ }^{5}$ L. Shestov, Potestas clavium. Vlast' klyuchey, [in:] id., Sochineniya v 2-kh tomakh, op. cit., Vol. I, p. 287. 
community can take place in different ways. In the approach proposed by Shestov, this way consists in "escaping". Shestov puts a clear emphasis on "escape", which is why I adopt the assumption that when the individual abandons society, then, apart from social development as a necessary condition, the individual's conscious decision preceded by his/her mental development is also necessary. The escaping person knows that $\mathrm{s} /$ he is escaping, and $\mathrm{s} / \mathrm{he}$ is doing it of her/his own free will.

The second aspect of the problem of the individual leaving the community is the context in which Shestov examines this question. This context is cognitive issues, one of the dominant areas in Shestov's reflections. In oversimplification, cognitive problems can be reduced to the problem of knowing the truth and the truth can be presented as a consequence of the individual leaving the community. Assuming that the necessary conditions for "essence of the particular and the individual" to manifest itself are fulfilled, the possibility arises of gaining the ultimate truth. This is what Shestov says on the subject: "Ultimate truth arises in utter secrecy and loneliness. It not only does not require but also does not admit of the presence of others. That is why it hates evidence and fears most what ordinary empirical truths live on - human recognition and definitive sanction"

We could thus say in the cognitive context that the individual's leaving of the community consists in doing away with the obstacles that make it impossible to know the truth. At another point Shestov illustrates this question with the example of Ariadne's thread - the thread that ties the individual to the world has to be broken so that the ultimate truth could be known ${ }^{7}$.

In Shestov's philosophy the individual's leaving of the community is described as an escape or severing of social ties. Regardless of the manner of description, the individual's abandonment of the community - as in the foregoing example of the yurodivy - does not, however, mean that the individual is outside of the community in the literal sense. The individual leaves society without going outside of it because the context for the activities of the individual possessing knowledge is still society, the difference being that the individual is no longer its constituent. This problem is clearly seen when Shestov discusses the problem of the individual's moral responsibility for others.

\footnotetext{
${ }^{6}$ Idem, Tol'ko veroyu. Grecheskaya i srednevekovaya filosofiya. Lyuter $i$ Tserkov', YMCAPRESS, Paris 1966, p. 284.

${ }^{7}$ Cf. L. Szestow, Apoteoza nieoczywistości. Próba myślenia adogmatycznego, transl. by N. Karsov, Sz. Szechter, Kontra, London 1983, pp. 33-34.
} 


\section{Autonomizing personality - the case of Solovyov}

If this discussion focuses only on Solovyov's grand social projects, i.e. theocracy and on the later ecumenism project, it should be said that Shestov, when stating that Solovyov escapes from the self to the community, accurately rendered the essence of the individual-community relationship.

In Solovyov's position an important role for social development is, however, played by the autonomization of individual personality, which, he believes, is the fundamental condition for creating philosophy. Taking this problem into account gives grounds for a conclusion that for Solovyov the process of social development is not as simple as Shestov presents it. In Solovyov's view the individual leaves society as a result of the emergence of personality. This means that in some cases of personal development, with specific conditions being fulfilled, the final effect of socialization is different from those usually assumed. Each time the next individual who has reached the autonomy of personality leaves society the result is the weakening or even decomposition of the social organism $^{8}$. On the other hand, however, only by leaving society can the individual attain knowledge, inter alia s/he gains knowledge of the "essence of the particular and the individual". In this case it is important that an individual acquires knowledge in loneliness.

In Solovyov - unlike what Shestov proposes later - knowledge about the essence of the individual will become sufficiently generalized for the individual as such, which in turn, despite many other premises, does not make it possible to interpret Solovyov's philosophy as existential philosophy $^{9}$.

Although the individual's leaving of society has negative consequences, they are more than compensated for due to the gained knowledge. In the final analysis this brings more benefits to society because the truth found in loneliness translates into effective practical actions. In Solovyov's philosophy this process is exemplified by the story of the superman from $A$ Short Story of the Antichrist. The superman is a lonely individual, who is a genius. On the basis of his knowledge he organizes social life for

\footnotetext{
${ }^{8}$ V. S. Solov'yev, Krizis zapadnoy filosofii (Protiv pozitivistov), [in:] id., Sochineniya v 2-kh tomakh, op. cit., Vol. II, p. 91. Cf. also, ibid, 6. Also on the subject cf. A. Ostrowski, Sołowiow. Teoretyczne podstawy filozofii wszechjedności, Wydawnictwo UMCS, Lublin 2007, p. 44 et seq.

${ }^{9}$ On the subject, cf. ibid., pp. 69, 361, 363.
} 
those who did not manage to leave society ${ }^{10}$. Like in theforegoing cases of the yurodivy and Shestov, also in Solovyov's philosophy the individual leaves society without going outside of it.

\section{Similarities and differences between the two models of organization of social life}

The starting point for analysis was the explicit opposition between the positions described by Shestov: escape from the community to the self (type A - the individual's total independence from the community); escape from the self to the community (type B - the individual's total dependence on the community). Yet a comparison of the examples of Solovyov and Shestov, who represent these positions, shows more common elements than differences. Was therefore Shestov wrong after all when he asserted that Solovyov escapes from the self to the community? Or perhaps he consciously adopted this interpretation because it suited him for some reasons? The latter possibility is highly probable because Shestov freely interpreted the works of many thinkers, Solovyov's philosophy being no exception.

The $C$ type of the individual-community relationship indicated as the common element in the philosophies of Solovyov and Shestov nevertheless gives grounds for saying that Shestov wrongly assesses his position and that of Solovyov. In a moderate version it can perhaps be accepted that Shestov's oversimplified manner of describing the two positions distorts their essence.

At a more detailed level of discussion we can distinguish more elements common to the positions of Shestov and Solovyov. The first is that both philosophers speak of the individual who leaves society. To Shestov, the abandonment of society means radically severing ties, escape, which is symbolized by breaking Ariadne's thread. To Solovyov, this means the process of autonomization of individual personality, the consequence being a total mental independence from others, resulting in the individual leaving society.

The second common element of the positions represented by the two philosophers is the cognitive context of the problem of the individualcommunity relationship. For Shestov the condition for knowing the truth was the rejection of the general and the necessary, including the rejection

\footnotetext{
${ }^{10}$ Cf. W. Sołowiow, Trzy rozmowy 1899-1900, [in:] id., Wybór pism, op. cit., Vol. II, p. 122 et seq.
} 
of social ties. The symbolic breaking of Ariadne's thread is a necessary condition for knowing the truth. Solovyov also speaks of cognition of the truth, the condition for it being to leave society. When speaking on this subject, Solovyov does not, however, exaggerate as Shestov does, there is no existential dilemma of either/or here. For Solovyov, knowing the truth is a consistently implemented process which, with the conditions being fulfilled, will result in the individual leaving society. One of the symptoms is being lonely among others, which manifests for example in the lack of understanding and acceptance of views with simultaneous admiration for the genius of an individual or, which happens far more often, for ignorance. Worth noting is that Solovyov does not exclude one-time cognition acts from the cognitive process, such as revelation or illumination. Nevertheless, the whole of the cognitive process is subjected to the rigors of rationalization. Solovyov's cognitive position is interpreted by Shestov precisely as rationalism, which at the same time was the main objection raised by Shestov against Solovyov's philosophy.

The third common element is the discovery of the "essence of the particular and individual". It is significant that the essence of the individual is fully revealed only in the context of the superior goal which is the salvation of the soul.

The fourth common element is ethical intellectualism. In both cases this position is obviously different from the classic, idealist standpoint represented by Socrates; nevertheless, the essence of ethical intellectualism is retained: knowledge compels the conduct that is analyzed both by Solovyov and by Shestov in terms of ethical duty.

The basic difference between Solovyov's and Shestov's positions consists in that the manner of conduct which stems from acquired knowledge is entirely dissimilar. It should be noted that in the context of their different positions another common element surfaces: it is the instrumental use of lying.

On the basis of the acquired knowledge Solovyov creates a system of theocracy, which he sets in the project of the philosophy of all-unity (всеединство). The individual who has left society following the process of personality autonomization gains knowledge and uses it to create a new model of social life. In this respect, Solovyov's achievements can be compared to Plato's model of the ideal state. In either case there are grounds for speaking about the individual's concern towards the community. In both cases the organization of social life arising from the possessed knowledge is not, however, an end in itself, but a way of achieving a superior goal. This goal is the salvation of the soul although, for obvious reasons, it is differently understood by each of the philosophers. 
When building his concept of the state, Plato resorts to lies meant as an instrument of exercising power, which plays a very important role together with the possessed knowledge. Plato does not speak directly about the necessity of using lies. However, one can easily conclude from his discussion on the detailed solutions introduced for the organization of social life that he assumes this necessity to be self-evident. It should be clearly emphasized that Plato's recourse to lies and refusal to share the secrets of knowledge with those who are not prepared for it yields positive results both in the material dimension (the abundance of goods to meet needs) and in the spiritual aspect (shortening the process of the transmigration of soul, thereby redeeming it sooner) ${ }^{11}$.

On account of the abovementioned analogy between the solutions introduced by Plato and Solovyov it should be asked whether the same can be said on the subject of lie in the case of Solovyov's philosophy? The reference to the project of theocracy and ecumenism and taking into consideration the ethical duty of the individual towards the community gives no grounds for saying that the individual who organizes social life uses lies for this purpose.

Assuming that $A$ Short Story of the Antichrist is a complement to the whole of Solovyov's philosophy, the answer to the question about the instrumental use of lies must however be in the affirmative. Desired by all the multicultural society, the effects of the actions by the superman (universal peace, the state of satiation, carnival) are based on knowledge and on lie. In contrast, taking the superman's actions into account it is difficult to support the thesis about ethical intellectualism. Despite positive and generally accepted results arising from the acquired truth one cannot say without reservations that the superman's actions are determined by ethical duty. In this case the principle of action is his ego and the need to be admired by others. The social order based on knowledge and lies is shown by Solovyov as necessary, this being a complete order, which means that it has its end in the earthly realities.

When talking about finding the truth by the individual, Shestov is in favor of an entirely different solution. Cognition of the truth results in that he does not propose a new social order. Unlike Plato and Solovyov, he resorts to lies in order to not introduce a new social order. The necessity of introducing a new social order stems from the gained knowledge. After attaining knowledge, the individual lies to the community, however, to conceal the "terrible" truth from it. S/he does it in

\footnotetext{
${ }^{11}$ Cf. A. Ostrowski, Filozof wobec klamstwa koniecznego - analiza problemu na przykładzie filozofii Lwa Szestowa, "Przegląd Filozoficzny - Nowa Seria" 2011, No. 1, pp. 100-101.
} 
the name of moral responsibility for others. As a result, despite having knowledge which necessitates the introduction of changes, $\mathrm{s} /$ he confirms the others' belief that the existing social order, however imperfect, is the right one. "»You should not lie«, the learned scholar keeps repeating to himself over and over again, and yet he cannot overcome his instinctive fear and keeps lying, lying, and lying. Not for his superficial personal convenience of the type: primum vivere, deinde philosophari - we are not interested in this case at all. The learned scholar lies, being motivated by higher reasons, and obeying the dictates of his conscience. It appears to him that if he starts telling the truth, if the truth is known to people, then life on Earth will be utterly impossible" ${ }^{\prime 2}$.

What is also characteristic of Shestov's philosophy is that he does not speak implicitly about the need to lie as do Plato and Solovyov. Shestov is explicit about the utility of lies, glorifying them for the sake of the common good (the good of the community). "However, under no circumstances do I think it necessary to choose: either the lie or the truth. Let the lie flourish and let even gnoseologists make songs in praise of the lie as one, best and most important truth - can this be an argument against the actual truth" ${ }^{\prime 13}$ ?

The comparison of Shestov's and Solovyov's positions yields surprising results. The discussion is based on the interpretive assumption that while gaining knowledge both Shestov and Solovyov discovered the same truth - "the essence of the particular and the individual". The essence of the individual, as has been already said, manifests fully only in the context of the superior goal, which is the salvation of the soul. The realization of this goal, however, has nothing to do with the earthly sphere of social life, it even excludes it, which I regard as one of the most important problems that can be found in the reflections of the two philosophers. This is also clearly exemplified by the activities of the yurodivy. It should be remembered that the salvation of the soul is the goal which is determined by knowledge (ethical intellectualism). When the moral principle of responsibility for others is referred to, the road to

\footnotetext{
${ }^{12}$ L. Szestow, Początki i końce. Zbiór artykułów, transl. by J. Chmielewski, Antyk, Kęty 2005 , p. 5 .

${ }^{13} \mathrm{Ibid}$., p. 88. For more on the problem of lying cf. A. Ostrowski, Filozof wobec klamstwa koniecznego..., op. cit., pp. 95-108.
} 
the realization of this goal is, however, different for the two philosophers. Consequently, the question should be asked which philosopher, Solo-vyov or Shestov, behaves in the poper way towards the community. Is it better, out of concern for the community, to lie while knowing the truth, at the same time convincing others of the need and necessity to build a new social order, or to lie, protecting others from the consequences of the truth and thereby to maintain the existing order? In both cases the consequences of the truth are inevitable, becoming apparent to the individual when s/he has cognized the truth. The issue is those who still do not know it.

\section{Bibliography}

Ostrowski A., Filozof wobec kłamstwa koniecznego - analiza problemu na przyktadzie filozofii Lwa Szestowa, "Przegląd Filozoficzny - Nowa Seria" 2011, No 1.

Ostrowski A., Solowiow. Teoretyczne podstawy filozofii wszechjedności, Wydawnictwo UMCS, Lublin 2007.

Shestov L., Afiny i Ierusalim, [in:] L. Shestov, Sochineniya v 2-kh tomakh, Nauka, Moscow 1993, Vol. I.

Shestov L., Kirkegard i ekzistentsial'naya filosofiya. Glas vopiyushchego v pustyne, Progress - Gnozis, Moscow 1992.

Shestov L., Potestas clavium. Vlast' klyuchey, [in:] L. Shestov, Sochineniya v 2-kh tomakh, Moscow 1993, Vol. I.

Shestov L., Sola fide - Tol'ko veroyu. Grecheskaya i srednevekovaya filosofiya. Lyuter i Tserkov', YMCA-PRESS, Paris 1966.

Solov'yev V. S., Krizis zapadnoy filosofii (Protiv pozitivistov), [in:] V. S. Solov'yev, Sochineniya v dvukh tomakh, Mysl', Moscow 1990, Vol. II.

Sołowjow W., Trzy mowy ku pamięci Dostojewskiego 1881-1883, [in:] W. Sołowjow, Wybór pism, transl. by J. Zychowicz, W Drodze, Poznań 1988, Vol. III.

Sołowjow W., Trzy rozmowy 1899-1900, [in:] W. Sołowjow, Wybór pism, transl. by J. Zychowicz, W Drodze, Poznań 1988, Vol. II.

Szestow L., Apoteoza nieoczywistości. Próba myślenia adogmatycznego, transl. by N. Karsov, Sz. Szechter, Kontra, London 1983.

Szestow L., Poczatki i końce. Zbiór artykutów, transl. by J. Chmielewski, Antyk, Kęty 2005.

Wodziński C., Pan Sokrates. Eseje trzecie, WIFiS PAN, Warszawa 2000. 
Wodziński C., Św. Idiota. Projekt antropologii apofatycznej, słowo/obraz terytoria, Gdańsk 2009.

\section{Zusammenfassung}

\section{Das Individuum gegenüber der Gesamtheit - Studium von zwei Beispielen}

Der Artikel setzt sich zum Ziel, die Beziehung Individuum - Gesamtheit zu besprechen. Den Kontext der Überlegungen bilden zwei Modelle der Organisation des Soziallebens, die von W. Solowjow und L. Szestow vorgeschlagen wurden. Das erste Modell kennzeichnet die Flucht von der Gesellschaft zu sich selbst, das zweite Modell die Flucht von sich selbst zur Gesellschaft. In folgender Betrachtungsweise werden diese Modelle als Folge der Wahrheitserkenntnis verstanden. Die Überlegungen stützen sich auf die interpretatorische Annahme, dass sowohl Szestow als auch Solowjow beim Wissensaneignen zur Erkenntnis derselben Wahrheit kamen - „der Bedeutung dessen, was einzeln und individuell ist".

Schlüsselworte: Individuum, Gesamtheit, Pflicht, Lüge

\section{Streszczenie}

\section{Jednostka wobec ogółu - studium dwóch przypadków}

Celem artykułu jest omówienie zagadnienia relacji jednostka - ogół. Kontekstem rozważań są dwa modele organizacji życia społecznego, które zostały zaproponowane przez W. Sołowjowa i L. Szestowa. Model pierwszy charakteryzuje ucieczka od społeczeństwa do siebie. Model drugi, ucieczka od siebie do spoteczeństwa. W ujęciu interpretacyjnym modele te sa rozumiane jako konsekwencja poznania prawdy. Rozważania oparte sa na interpretacyjnym założeniu, że zarówno Szestow jak i Sołowjow, zdobywając wiedzę, odkryli tę samą prawdę - ,znaczenie tego, co poszczególne i indywidualne”.

Słowa kluczowe: jednostka, ogół, powinność, kłamstwo

Information about Author:

ANDRZEJ OSTROWSKI, habilitated doctor, Maria Curie-Skłodowska University in Lublin, Poland; address for correspondence:, Pl. M. Curie-Skłodowskiej 4, 20-031 Lublin, Poland; e-mail: aostrowski@bacon.umcs.lublin.pl 